\title{
Effectiveness of the Quality of Life Training in a Dairy product manufacturing company in Trichy
}

\author{
Suthakar Singh S, Sathyapriya J, KVR Rajandran
}

\begin{abstract}
A person with good behavior can only be a good employee. Years ago, the work life and personal life of any person were independent and measured separately in lieu of the quality of life. Now, researches showed that they are interrelated and the quality of personal life influenced the quality of work life. The improvement in behaviour of the employees had a vital role in their personal as well as work life. This enabled the industries to train their employees to improve their behavior and attitude. This study analysed the effectiveness of the Quality of Life training programme, in various aspects and found the relationship between various factors which were related to human life by using multiple regression. The sample size selected was 132 among the population of 200 employees working in a dairy product manufacturing company in Trichy, using simple random sampling technique.
\end{abstract}

Index Terms: Confidence level, Employee involvement, Quality of life and Social responsibility

\section{INTRODUCTION}

Quality of life is expressed by the degree of satisfaction in a person's life. A person who enjoyed all the pleasures in personal life can only contribute to the welfare of the society. This is applicable to the organisations also. If the employee of any organisation is happy in personal life, then only that person can contribute to the improvement of the organisation full hearted. The living condition of a person like house, the amenities, happy environment in house, financial stability in life, family members' relationship and relationship with the neighbors influence the personal life and its quality. Work place amenities, peer employees relationship and salary influence the quality of work life. If the satisfaction of a person in work place analysed, then it becomes quality of work life. Improved quality of work life, results in improved productivity. The quality of work life of an employee is mostly based on the safe work environment, Job security and salary. If these factors are satisfactory in the workplace, then the job involvement will increase with the result of more productivity. Quality of life training programmes improves the self confidence and the social responsibility.

Revised Manuscript Received on July 05, 2019.

Suthakar Singh S, Department of Management Studies, Periyar Maniammai Institute of Science \& Technology, Thanjavur, India.

Sathyapriya J, Department of Management Studies, Periyar Maniammai Institute of Science \& Technology, Thanjavur, India.

KVR Rajandran, Department of Management Studies, Periyar Maniammai Institute of Science \& Technology, Thanjavur, India.
Self confidence enforces the employees to take up challenges in the work place. Hence, with good attitude and behavior the individual will have a good life style, willing to learn new things and good interpersonal relationships. As a whole these training programmes are offered for the social empowerment of the employees.

\section{REVIEW OF LITERATURE}

Hassan, Narehan (2014) explored that the quality of work life programmes have considerable relationship with the Quality of life of the employees. The researcher suggested the organisation to do these programmes regularly in order to improve their overall organisational performance.

Indumathy.R. (2012) suggested the organizations to focus balancing the work life and personal life of the workforce to improve their productivity.

Lokanadha Reddy. M (2010) concluded that the management contribution is very much important in the improvement of quality of work life of the employees. It was found that the techniques improving the employee involvement in workplace also improved the quality of life.

Nanjundeswaraswamy (2013) found that the payment and rewards were more associated with the quality of life of the employees.

Shefali Srivastava (2014) concluded that the outcome of improved Quality of life finally gave high degree of performance in the employees' productivity. Positive attitude of employees improved and ultimately organisational performance increased.

Sulbha Waghmare (2017) found that the harmony in work place and good ethnicity of the organisation were the keys to develop the quality of life of the employees. The researcher specified that the Quality of work life is the brilliant tool for the Human Resources Managers to ensure a positive result in the organisation.

\section{METHODOLOGY}

\section{A. Research Design}

The research design is used for the study is descriptive. The research was done in a dairy product manufacturing company in Trichy. The sample size was 132 among 200 employees were chosen using Simple Random Sampling. A structured 
questionnaire was administered for data collection and multiple regression analysis was used for analysis.

\section{B. Research Objective}

To measure the effectiveness of the Quality of Life training programme on the personal life factors.

\section{RESULTS AND DISCUSSION}

\section{A. Hypotheses}

$\mathbf{H}_{\mathbf{0}}$ : There is no significant relationship between the dependant variable and independent variables.

$\mathbf{H}_{1}$ : There is significant relationship between the dependant variable and independent variables.

\begin{tabular}{|c|c|c|c|c|}
\hline \multicolumn{5}{|c|}{ Model Summary } \\
\hline $\begin{array}{c}\text { Mode } \\
\mathbf{l}\end{array}$ & $\mathbf{R}$ & R Square & $\begin{array}{c}\text { Adjusted } \\
\text { R Square }\end{array}$ & $\begin{array}{c}\text { Std. } \\
\text { Error of } \\
\text { the } \\
\text { Estimate }\end{array}$ \\
\hline 1 & 0.911 & 0.830 & 0.808 & 0.202 \\
\hline
\end{tabular}

a. Predictors: (Constant), Good Citizen of the country, Follow traffic rules, Loyalty to the company, Willingness to Learning, Take up challenges, Confidence Level low before training, Believe as a skilled person, Interpersonal Relationship, Take up challenges in workplace, Responsible for ups and downs, Environment friendly, Confidence Level improved after training, Responsible family member, Don't use tobacco, Family budget

b. Dependent Variable: Training Effectiveness

The regression value $\mathrm{R}$ square is 0.830 . It is understood that there is a significant effectiveness in the Quality of Life training programme.

\begin{tabular}{|l|l|c|c|c|c|c|}
\hline \multicolumn{7}{|c|}{ ANOVA $^{\text {b }}$} \\
\hline \multicolumn{2}{|c|}{ Model } & $\begin{array}{c}\text { Sum of } \\
\text { Squares }\end{array}$ & df & $\begin{array}{c}\text { Mean } \\
\text { Square }\end{array}$ & F & Sig. \\
\hline \multirow{2}{*}{1} & Regression & 23.334 & 15 & 1.556 & 38.148 & $.000^{\mathrm{a}}$ \\
\cline { 2 - 7 } & Residual & 4.771 & 117 & 0.041 & & \\
\cline { 2 - 7 } & Total & 28.105 & 132 & & & \\
\cline { 2 - 7 } & & & & & \\
\hline
\end{tabular}

a. Predictors: (Constant), Good Citizen of the country, Follow traffic rules, Loyalty to the company, Willingness to Learning, Take up challenges, Confidence Level low before training, Believe as a skilled person, Interpersonal Relationship, Take up challenges in workplace, Responsible for ups and downs, Environment friendly, Confidence Level improved after training, Responsible family member, Don't use tobacco, Family budget

b. Dependent Variable: Training Effectiveness

Above ANOVA table shows that significance $(p)$ value < 0.05 , which means $\mathrm{H}_{0}$ is rejected therefore there is a significant relationship between the dependant variable

Training effectiveness and independent variables in the Quality of Life training programme. A significant regression equation is found $\mathrm{F}(15,117)=38.148, p<0.000$, with an $\mathrm{R}^{2}$ of 1.556 .

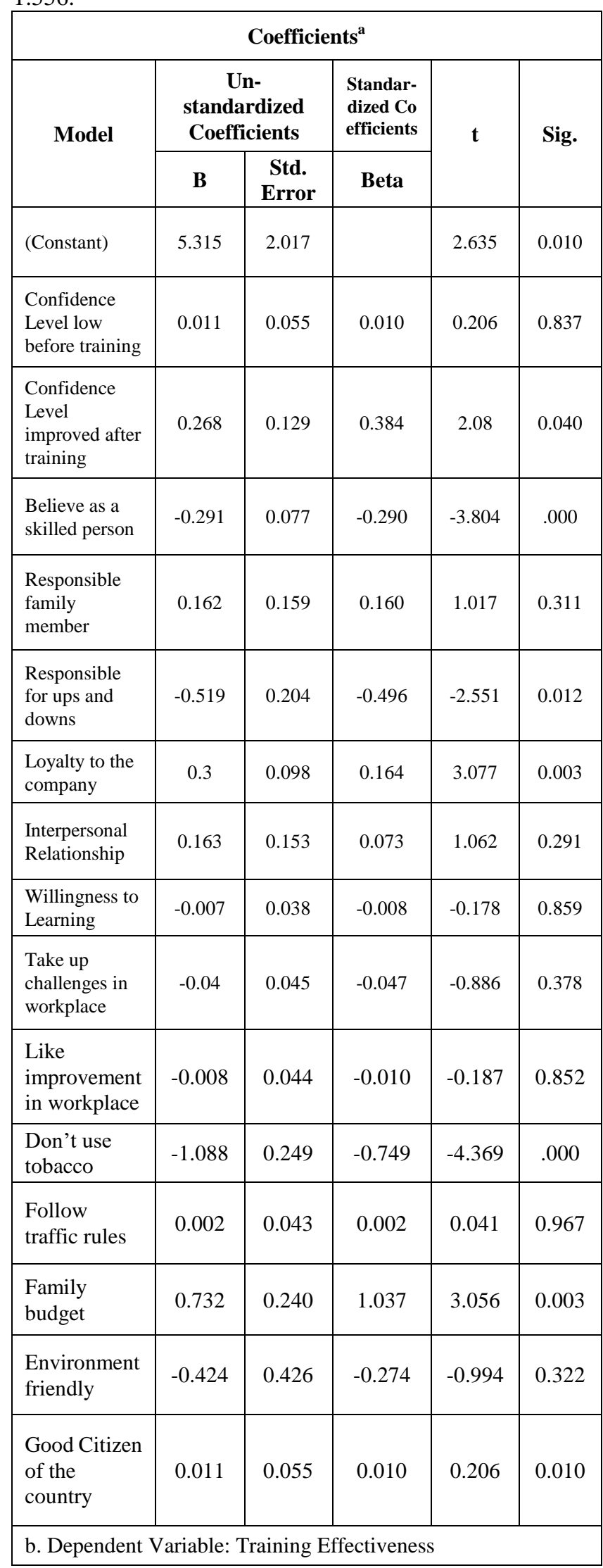


With $p$ value 0.003 and Beta value 1.037 the variable Family budget has the highest impact with the effectiveness of the Quality of life training programme. The other variables Loyalty to the company, Confidence Level improved after training, Good Citizen of the country are highly significant in the effectiveness of the Quality of life training programme.

Even the personal comfort level variables Believe as a skilled person, Responsible for ups and downs and Don't use tobacco also have significant effectiveness with respect to $p$ value < 0.05 they have the smallest contribution to the effectiveness of the Quality of life training programme.

\section{CONCLUSION}

The research results show that the Quality of life training programme is effective in various aspects. As the variable Family budget has the highest impact, this shows that most of the employees in the company are family oriented and fulfilling the financial need of their family is the priority for everyone. The result clearly shows that the employees are ready to contribute in the work place to maintain the financial stability of their family only. Hence, the quality of personal life is mainly based on the financial benefits and the Quality of training programme is much effective in the workplace.

\section{REFERENCE}

1.Lokanadha Reddy. M, "Quality of work life of employees: emerging dimensions”, Asian Journal of Management Research, 827 - 839, 2010.

2. Indumathy.R, "A study on quality of work life among workers with special reference to textile industry in Tirupur district - A textile hub", International Journal of Multidisciplinary Research , Volume 2, Issue 4, $265-281,2012$.

3. Nanjundeswaraswamy, "Quality of Work life of Employees in Private Technical Institutions" International Journal for Quality Research Volume 7, Issue 3, 3-14, 2013.

4. Hassan, Narehan, "The Effect of Quality of Work Life (QWL) Programs on Quality of Life (QOL) Among Employees at Multinational companies in Malaysia". Procedia - Social and Behavioral Sciences 112, 24 - 34, 2014.

5. Shefali Srivastava, “A Study on Quality of Work Life: Key Elements \& It's Implications", IOSR Journal of Business and Management (IOSR-JBM), Volume 16, Issue 3, 54-59, 2014.

6. SulbhaWaghmare, "Quality Of Work Life And Influencing Factors" International Journal of Advanced Research (IJAR), Volume 5, Issues $51328-1332,2017$. 